\title{
Review
}

\section{A Review of Laser Enhanced Plating and Etching for Electronic Materials}

\begin{abstract}
レーザー加速めっきおよびエッチングに関する理論と応用について，特にマイクロエレクトロニクス材料 への応用について解説を行ら。ニッケル, 金, 銅電析に関して金属化した基板上にフォトマスクを使わずフ ルゴンレーザーを利用してめっきする方法について概説する。 $0.5 \mathrm{~mm}$ スポットの金メッキではレーザーを 用いるとベリリウム銅基板上で通常の金めっきの場合の数 10 倍の速度である $10 \mu \mathrm{m} / \mathrm{s}$ にまで析出速度を上 げることが可能である. スチール，シリコンおよびセラミックスのエッチングについてのレーザー加速エッ チングについてむ解説する.
\end{abstract}

\section{Introduction}

Laser enhanced plating and etching have become increasingly interesting in recent years as a method of rapid maskless patterning. Such patterning is particularly useful in the microelectronics industry where applications to circuit design and circuit repair are most of ten cited. The ability to focus the laser to dimensions on the order of an optical wavelength in combination with the highly non-linear plating/ etching enhancement rates as a function of laser power in the region exposed to the focused radiation makes it possible to access and pattern micron sized regions with minimal background effects. This localization feature produces patterning without the use of masks. The present discussion will describe plating/ etching processes that are primarily photothermal and will not describe the many photochemical processes that can also be utilized for maskless patterning.

\section{Laser Enhanced Plating : Early Experiments}

The experimental arrangement that was first used to demonstrate laser enhanced plating is shown in Fig. 1 and in conjunction with a

* IBM T.J. Watson Research Center

P.O. Box 218

Yorktown Heights, NY 10598,U.S.A.
$\mathrm{NiCl}_{2}$ solution. The following results were obtained : 1) Localized plating in the region of absorbed laser radiation at rates up to $10^{3}$ times faster than background rates ${ }^{1,2}, 2$ ) the ability to deposit $\mathrm{Ni}$ on substrates normally difficult or nearly impossible to electroplate by conventional means, 3) the etching of holes in stainless steel on the order of $50-100 \mu \mathrm{m}$ in

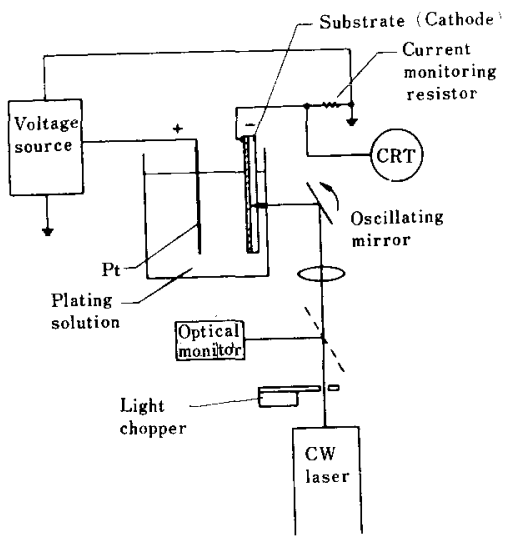

Fig. 1 Plating cell showing laser beam directed through the transparent sample to be incident on the glass-metallized predeposited film interface ${ }^{1)}$. Shown also are scanning mirror, chopper and laser. An additional mirror, not shown, can be interposed to bring the laser to the electrolyte-metal surface, i.e., front illumination. A dropping resistor is used to measure current flow, in particular, current with and without laser illumination. 
diameter, 4) the thermal nature of the plating/ etching mechanism. This was verified by directing laser light to the metallized substrate surface from two directions, from the solution to the metal and from the optically transparent substrate side to the absorbing metal using the apparatus of Fig. 1 with an additional adjustable mirror not shown. For laser illumination through the transparent glass substrate, no photons reach the electrolyte dut to the $2-3000 \AA$ thick premetallization. However, the depositions from both front and interfacial laser irradiation were found to be essentially the same in diameter and thickness. Hence photons cannot play an important role as excitation sources of the interface, while heat generated by photon absorption is equivalent for the two experiments. By using two substrates of widely differing thermal conductivity, i.e., thin films deposited on glass and on single crystal sapphire, it was found that the latter gives rise to thinner depositions covering however a larger area than that obtained with the glass substrates. These results are consistent with pyrolytic mechanisms with the higher conductivity material giving rise to less heat localization and hence a wider but thinner depostiton.

A more detailed investigation of the plating mechanisms was subsequently undertaken utilizing a three electrode potentiostat to study the $\mathrm{Cu} / \mathrm{Cu}^{2+}$ system $^{3)}$. For these experiments, a special electrode was constructed having a diameter on the order of that of the focused laser beam at the point of incidence on the cathode. This was achieved using a metallized glass substrate covered entirely, except for a small hole, with a photoresist layer acting as an insulator, Fig. 2. To study the laser plating enhancement as a function of overpotential,

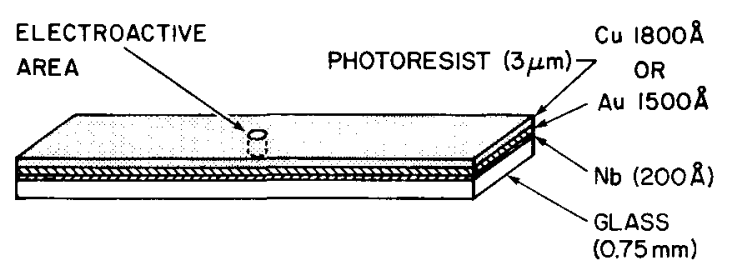

Fig. 2 Sturcture of a metallized-glass cathode using photoresist to produce a small electroactive area, approximately equal in size to the focused laser beam diameter ${ }^{3)}$.

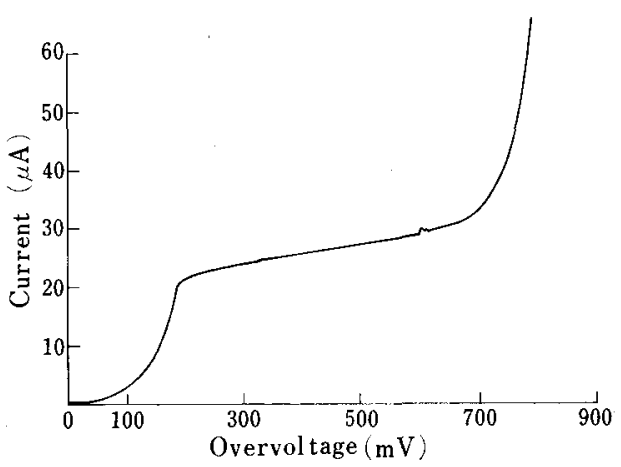

Fig. 3a Polarization curve for copper electrodeposition (current and overvoltage are negative); electrode diameter, $550 \mu \mathrm{m}$ [Ref. 3].

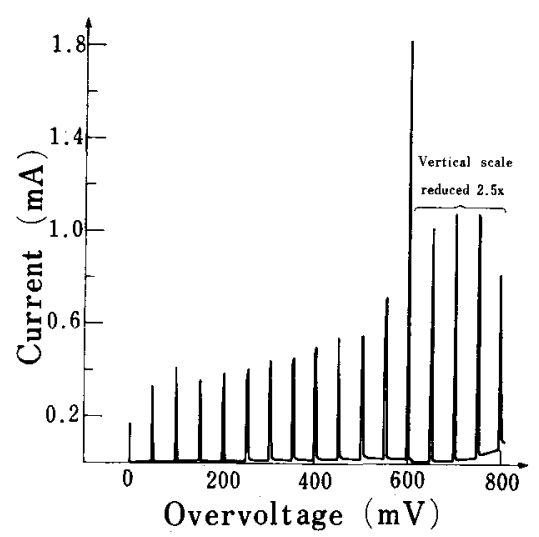

Fig. $3 \mathrm{~b}$ Polarization curve for the electrode with $200 \mu \mathrm{m}$ diameter active area. Laser power, 210 $\mathrm{mW}\left(6.7 \times 10^{2} \mathrm{~W} / \mathrm{cm}^{2}\right)$. Laser is applied at $50 \mathrm{mV}$ intervals causing large current spikes").

polarization curves were taken both with and without the laser directed through the hole onto the small cathode. Fig. 3 a shows the current dependence on overvoltage without the laser, while Fig. $3 \mathrm{~b}$ gives the dependence with periodic laser radiation $\left(6.7 \times 10^{2} \mathrm{~W} / \mathrm{cm}^{2}\right.$ argon ion laser) applied at $50 \mathrm{mv}$ intervals. The temperature at the interface is estimated to be $\sim 120^{\circ} \mathrm{C}$ in the steady state for this incident flux. A comparison of the curve of $b$ ) with and without the laser gives a direct measure of the plating enhancement afforded by the laser by the laser assuming comparable plating efficiencies. It is evident that a larger enhancement occurs at the larger overpotential up to the point of hydrogen evolution. The fact that a finite current flows at zero overpotential is due to a shift in the equilibrium (rest) potential to more positive values with in- 
creasing temperature. Thus, at zero overpotential the enhancement factor, i.e., ratio of plating current with and without the laser, approaches infinity.

The results of experiments utilizing these small cathodes have helped to elucidate the following principal laser plating mechanisms ${ }^{3 \sim 5}$ : 1) At low overpotentials where plating is kinetically controlled, a local increase in temperature increases the charge transfer rates and hence the plating current. The plating current density is given at low overpotentials by the Butler-Volmer equation :

$$
i=i_{0}\left[\exp (1-\beta)-\frac{\eta F}{R T}-\exp \left(-\beta \frac{\eta F}{R T}\right)\right]
$$

where $\beta$ is an exchange coefficient, $\eta$ the overpotential, $i_{0}$ the exchange current density, $R$ the gas constant, and $T$ the absolute temperature. The exchange current density is given by

$$
i_{0}=n F \frac{k T}{h} C_{\mathrm{A}} \exp \left[-\left(\triangle G_{\mathrm{C}}+\beta F \triangle \phi_{\mathrm{e}}\right) / R T\right]
$$

where $n$ is the number of charges per atom undergoing reduction, $F$, Faraday's constant, $\triangle G_{\mathrm{C}}$ the chemical free energy of activiation, $C_{\mathrm{A}}$ the ion concentration $/ \mathrm{cm}^{2}, h$, Planck's constant, $k$, Boltmann's constant, and $\triangle \phi_{\mathrm{e}}$ the equilibrium potential. The temperture dependence of $i_{0}$ is dominated by an Arrhenius term, $\exp \left(-\triangle G_{\mathrm{C}} / R T\right)$. Therefore, the kinetics of the reaction always increase with increasing temperature, irrespective of $\triangle \phi_{\mathrm{e}}$ (since $\triangle G_{\mathrm{C}}$ is positive and greater in absolute magnitude than $\triangle \phi_{\mathrm{e}}$ ). 2) A shift in the rest potential, $\triangle \phi_{\mathrm{e}}$ to a more positive value occurs for the system $\mathrm{Cu} / \mathrm{Cu}^{2+}$ with increasing temperature. This positive shift takes place with certain electrolytes including the gold/gold cyanide interface. The temperature dependence of $\triangle \phi_{\mathbf{e}}$ has the effect of shifting the entire overpotential curve to the left (Fig. $3 \mathrm{~b}$ ) in the region of the cathode undergoing laser heating giving rise to a higher current for a fixed overpotential. The temperature dependence of $\triangle \phi_{e}$ is obtained from the negative entropy change of the system where

$$
\frac{\mathrm{d} \triangle \phi_{\mathrm{e}}}{\mathrm{d} T} \propto \frac{\partial \triangle G_{\mathrm{C}}}{\partial T}=-\triangle S^{\circ}
$$

with $S^{\circ}$ the entropy. In general, this can give a positive or negative value, for $\mathrm{d} \triangle \phi_{\mathrm{e}} / \mathrm{d} T$ and has been found to be negative for $\mathrm{NiSO}_{4}$, sodium citrate plating solution in contact with a $\mathrm{Ni}$ electrode $^{3}$. 3) A large plating enhancement in the mass transport limited current region occurs due to the local microstirring of the fluid driven by the large thermal gradients produced by local laser absorption at the cathode. Additional stirring can also occur as a result of nucleate boiling. The fluid agitation brought about by local stirring and boiling causes a resupply of ions to the otherwise depleted region. The limiting current density, $i_{1}$,

$$
i_{1}=\frac{n F D C}{\delta}
$$

is thereby increased by virtue of the decrease in the duffusion length, $\delta$. Here, $D$ is the diffusion constant which is also temperature dependent, increasing with increased temperature and $C$ the molar concentration far from the cathode (bulk concentration).

\section{Other Types of Laser Enhanced Plating}

The nature of the enhancement mechanisms as outlined in the previous section gives rise to two additional types of laser enhanced plating which utilize no external driving force (EMF source). These electroless plating effects have both been experimentally verified in earlier reports ${ }^{3 \sim 5}$. In laser enhanced electroless plating, relatively fast plating rates occur in the region of laser absorption while virtually no background plating takes place elsewhere. Charge balance is maintained via a catalytic reducing agent incorporated in the solution. Experiments with electroless nickel deposits resulted in rates of $\sim 1000 \AA$ /s on metallized glass and activated glass substrates using $2-3 \mathrm{~W}$ of focused argon laser light. Thermobattery or laser enhanced exchange plating occurs when there is a shift in the rest potential to a more positive value with increasing temperature ${ }^{3 \sim 5}$. As the region absorbing laser light increases in temperature relative to the rest of the substrate, the local shift in rest potential causes increased plating in the hotter region with simultaneous etching 
in the cooler peripheral regions. The simultaneous plating and ecthing maintains charge conservation and overall charge neutrality. For a glass substrate with a metallized coating undergoing this form of deposition, the plating process continues at the center until the peripheral region is etched away, producing electrical isolation of the center region. For those electrolytes possessing a negative temperature shift in rest potential, dissolution (etching) occurs in the center with a simultaneous peripheral build-up (plating) as observed for $\mathrm{NiSO}_{4}$ in conjunction with a nickel coated substrate $^{3)}$. The thermobattery effect for gold depositions has been demonstrated extensively using a computer controlled table to move the cathode with respect to the laser to form a variety of patterns ${ }^{6)}$.

\section{Recent Results : Gold Depositions}

Recent interest in laser enhanded plating has centered on high speed deposition of gold $^{6 \sim 9)}$. This metal is of particular interest to the microelectonics industry where large quantities of gold and other precious metals are required for electrical contact areas on circuit boards and pin connectors. With present deposition techniques, gold becomes deposited where it is not required, causing considerable waste of this precious metal. The substrate material commonly used for these macroelectronic connectors is nickel plated $\mathrm{Be}-\mathrm{Cu}$, which has proven difficult to mask, resulting in gold consumption far greater than necessary. A high speed localized plating can therefore save time, as well as precious metal and space costs. The space saving occurs from the use of smaller plating tanks, made possible by the reduced time that the part has to be in contact with the plating solution. This, in turn, makes it possible to maintain a smaller gold inventory, an additional cost saving. Work on laser enhaced gold depositions in the form of 0.5 $1 \mathrm{~mm}$ diameter spots and $100 \mu \mathrm{m}$ wide lines on nickel plated $\mathrm{Be}-\mathrm{Cu}$ substrates has been previously reported ${ }^{7}$. These experiments utilized commercially available gold sulfite and gold cyanide plating solutions. It was found that laser enhanced electroplating rates as high as $1 \mu \mathrm{m} / \mathrm{s}$ could be achieved using Autronex 55
GV (Selrex Corp., Nutley, NJ) without Co or $\mathrm{Ni}$ additives, resulting in soft gold deposits. These experiments used up to $20 \mathrm{~W}$ of argon laser power focused to spots of $0.5-1 \mathrm{~mm}$ diameter. Depositions were made under a variety of electrochemical and laser parameters. Examination of both cross sectioned deposits and SEM micrographs of the deposited surfaces was used to analyze their quality. Attempts to laser deposit at higher depositien rates resulted in dendritic and porous morphologies belived to occur due to plating at or above the limiting current density, Eq. 4. Under these high currents a poor morphology results due to the lack of a sufficient resupply of ions, i.e., mass transort limitations. An example of a quality laser plated gold spot on $\mathrm{Be}-\mathrm{Cu}$ is shown in Fig. 4. The smooth surface morphology is typical of very small grain size. The cross sectioned gold indicates a dense deposit, pore and void free. This spot was deposited at a rate of $1 \mu \mathrm{m} / \mathrm{s}$ in contrast to a maximum rate of $0.1 \mu \mathrm{m} / \mathrm{s}$ observed for a highly agitated solution utilizing otherwise standard plating technology ${ }^{10)}$. Other attempts at laser enhaced plating of gold on metal substates have used intermediate deposition of lower thermal conductivities to enhance the local temperature rise from the laser radiation ${ }^{11}$.

A method to greatly increase the mass transport over and beyond that afforded by the laser microstirring has been recently developed yielding an order of magnitude increase in plating rates over the earlied reported rate for laser enhanced gold deposition ${ }^{12)}$. A schematic of this technique, termed laser enhanced jet plating, is shown in Fig. 5. Here, a free standing jet of electrolyte emanating from a

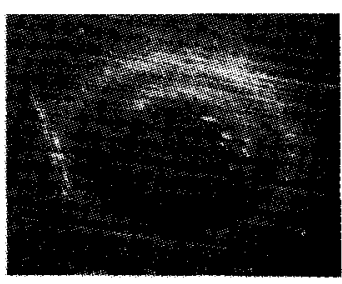

a)

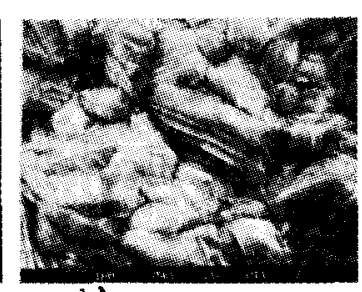

b)
Fig. 4 a) Surace of laser plated spot using Autronex $55 \mathrm{GV}$, pure gold. b) High magnification SEM, the deposit showing in detail the excellent surface morphology $y^{7}$. 


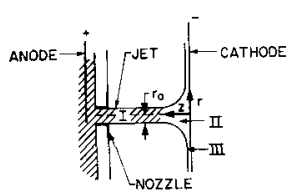

(d)

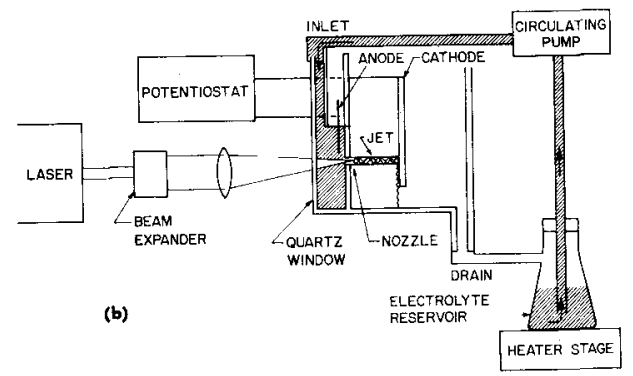

Fig. 5 a) Diagram of free jet (no laser) showing fundamental regions of jet of radius $r_{0}$, region I ; II stagnation fiow region with $r$ and $z$ dependence for velocity of jet and electric fields. Region III, wall jet, velocity and current varies mainly in the $r$ direction and carries low current densities since wall jet is thin and hence much more resistive compared to stagnation region ${ }^{12}$.

pressurzed chamber through a nozzle impinges on the cathode. The anode, housed in the pressure chamber, consists of shim stock of gold or platinum with a hole sufficiently large to allow passage of the laser light prior to its passage through the nozzle. Anode-cathode current flow is limited to the region of the jet column. Deposition occurs mainly in the stagnation region (Fig. $5 \mathrm{a}$ ) and to a much lesser degree extends radially into the wall jet region. The current density in the wall jet much smaller than in stagnation region so that plating rates are proportionately smaller. The jet stream in the laser-jet configuration also serves as a light guide for the beam directing the radiation to the cathode to form a laser enhanced jet plating system. Most of the light absorstion occurs in the stagnation region at the cathode so that the peripheral plating is not laser enhanced. The cathode (substate) in these experiments was mounted on an arm attached to the computerized precision table for patterning using the relative motion of the cahtode with respect to the stationary nozzle and jet. A summary of hydrodynamic and laser parameters used for gold patterning experiments is presented in Table 1. Figure 6 shows optical micro-
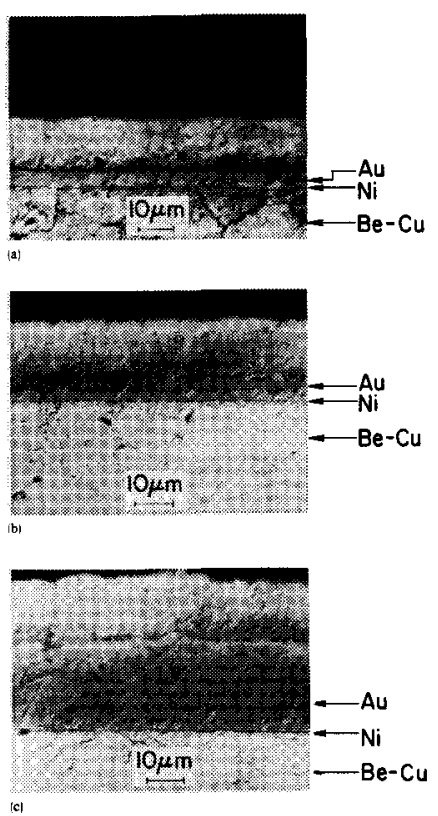

Fig. 6 Cross-seccions of laser gold on nickel plated $\mathrm{Be}-\mathrm{Cu}$ substrates, $200 \mu \mathrm{m}$ thick; Plating current density, $11 \mathrm{~A} / \mathrm{cm}^{2}$. Top layer is electrodeposited nickel to protect gold during crosssectioning and polishing. Laser-jet plating times and resulting thicknesses are : a) $0.5 \mathrm{~s}, 4.5 \mu \mathrm{m}$ b) $1 \mathrm{~s}, 8 \mu \mathrm{m}$ c) $5 \mathrm{~s}, 30 \mu \mathrm{m}$ [Ref. 12].
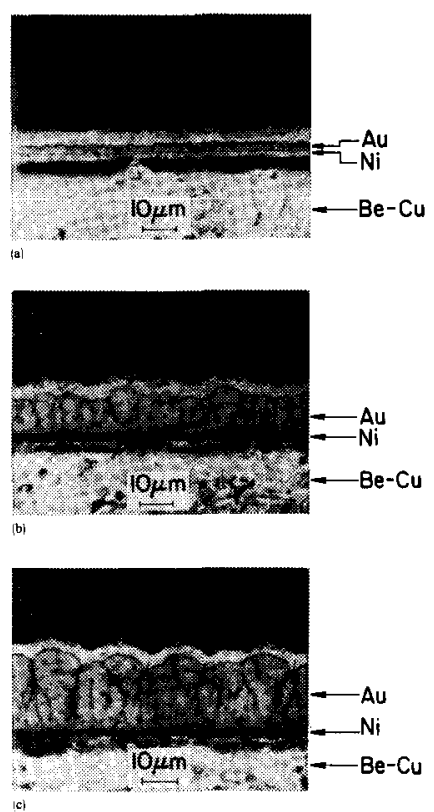

Fig. 7 Cross-sections of jet plating, but without the laser, Substrates and current densities as in Fig. 6. a) $1 \mathrm{~s}, 3 \mu \mathrm{m}$ b) $5 \mathrm{~s}, 12.5 \mu \mathrm{m}$ c) $10 \mathrm{~s}, 25 \mu \mathrm{m}$. Note voids throughout gold deposit, deposit, independent of gold thickness ${ }^{12)}$. 
Table 1 Gold plating solution and laser-jet cell parameters

\begin{tabular}{|c|c|}
\hline Gold solution & $\begin{array}{l}\text { Sel-Rex* Autronex } 55 \mathrm{GV} \text {, } \\
\text { Au cyanide, no additives, } \\
4 \text { Tr. Oz. Au/gal }\end{array}$ \\
\hline Solution temperature & $60^{\circ} \mathrm{C}$ \\
\hline Jet orifice & $\begin{array}{l}0.05 \mathrm{~cm} \text { diameter, } \sim 0.2 \mathrm{~cm} \\
\text { long }\end{array}$ \\
\hline Linear flow velocity & $1.0 \times 10^{3} \mathrm{~cm} / \mathrm{s}$ \\
\hline Reynolds number & $5.5 \times 10^{3}$ \\
\hline Nozzle-cathode spacing & $\sim 0.5 \mathrm{~cm}$ \\
\hline Plating current density & $1-16 \mathrm{~A} / \mathrm{cm}^{2}$ \\
\hline $\begin{array}{l}\mathrm{cw} \text { Laser power into } \\
\text { jet }\end{array}$ & $\sim 25 \mathrm{~W}$ maximum \\
\hline
\end{tabular}

* Sel-Rex, Div. of Oxy-Metal Industries Corp., Nutley, NJ 07110.

scope photographs of cross sectioned laser plated gold deposits on nickel plated $\mathrm{Be}-\mathrm{Cu}$ substrates using parameters of Table 1. For comparison, Figure 7 shows cross-sectioned samples made identical conditions except without laser radiation. The important features of the laser jet samples are 1) plating rates up to $10 \mu \mathrm{m} / \mathrm{s}$ for incident power levels of $20 \mathrm{~W}, 2$ ) void free dense deposits of excellent metallurgical quality, 3) good adhesion to the substrate. In contrast, the samples prepared with the jet and no laser power show void formation independent of film thickness. This indicates that at these high current densities, voids are initiated very near the nucleating surface and propagate into the film as it grows to larger thicknesses. Jet plated gold samples without voids could not be grown at rates faster than $1 \mu \mathrm{m} / \mathrm{s}$. We surmise that the laser radiation and the resulting local heat may be annealing the film during deposition while also enhancing nucleation sites on the sample substrate. The latter effect can be due in part to laser substrate cleaning of a thin oxide layer. The dissolution of this oxide occurs during the initial interval of laser absorption and consequent local heating.

For the high plating rates afforded by this method, it is possible to consider an automated reel to reel plating system for the manufacture of gold contacts on $\mathrm{Be}-\mathrm{Cu}$ parts. For the $1-2 \mu \mathrm{m}$ gold thicknesses generally required, a rate of $10 \mu \mathrm{m} / \mathrm{s}$ permits plating in $100-200 \mathrm{~ms}$, or a throughput of up to $10 \mathrm{parts} / \mathrm{s}$ for a single $20 \mathrm{~W}$ laser directed through a single nozzle. Both hard and soft gold can be plated by this method.

The laser jet electroplating technique has recently been applied to copper electrolytes for high speed maskless copper plating. Preliminary results indicate the main effect of the laser is to improve the surface morphology of the copper deposits. Plating rates, on the other hand, did not appreciably increase for molar concentrations of $\mathrm{CuSO}_{4}$ in the range $0.2-1.0$ $M$, a behavior quite different from that observed for gold. Further investigations of the $\mathrm{Cu}$ system using the laser jet arc continuing.

\section{Laser Etching}

By reversing the polarity of the cathode and anode of the experimental arrangement of Fig. 1 , laser enhanced etching has been achieved ${ }^{1,2)}$. This etching technique has been used to produce $50 \mu \mathrm{m}$ diameter holes in stainless steel stock (Fig. 8) using $\mathrm{NiCl}_{2}$ solution as the electrolyte ${ }^{5}$. It is also possible to obtain high speed laser enhanced etching without the use of externally applied potentials. We have demonstrated enhanced chemical etching (machining) by patterning a variety of ceramics as well as single crystal silicon using an intense laser beam to locally melt the substate ${ }^{13)}$. In these experiments the high local temperatures caused intense stirring of the solution thereby allowing fresh ions to enter the region undergoing laser processing while simultaneously dispersing the reacted fluid. The local temperature increase also causes an increase in the chemical reactions which are thermally acti-

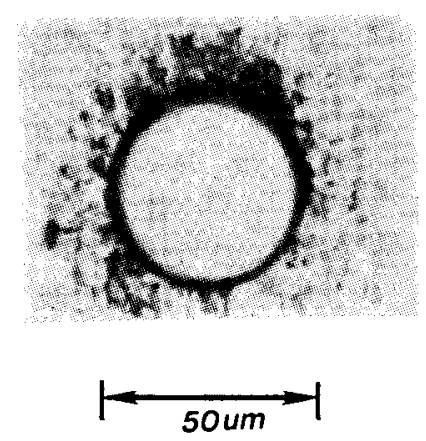

Fig. $850 \mu \mathrm{m}$ diameter hole electroetched in 50 $\mu \mathrm{m}$ thick stainless steel shim stock ${ }^{5}$. No post processing was used to obtain shape. 


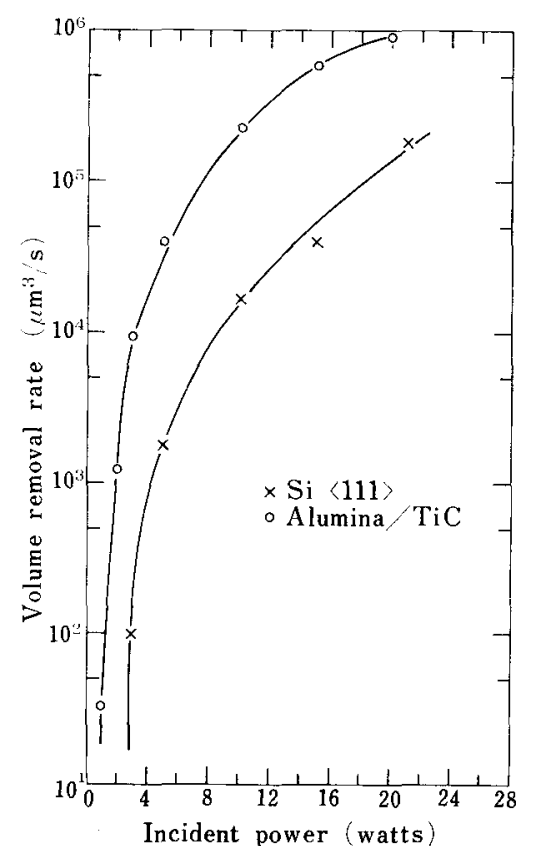

Fig. 9 Volume removal rate vs. laser power for alumina/TiC ceramic and (111) silicon (Curves drawn as aid to the eye) ${ }^{133}$.

vated.

Etching rates in terms of volume removal for (111) $\mathrm{Si}$ processed in concentrated $\mathrm{KOH}$ are shown in Fig. 9 as a function of incident laser power. Under standard etch conditiions, $\mathrm{KOH}$ will not etch this crystal orientation but will etch (100) Si strongly. In the present experiments, however, the intense heat produces local melting and consquently a loss of any crystal symmetry. Figure 9 also shows the rates for the etching of alumina/TiC, a ceramic used in a number of important microelectronic applications. The etch rates for this material are approximately an order of magnitude higher than $\mathrm{Si}$ for a fixed incident laser power. For $\mathrm{Si}$, an average etch rate of $15 \mu \mathrm{m} / \mathrm{s}$ has been observed in the laser etching of through holes in $10 \mathrm{mil}$ wafers using a power density of $10^{7} \mathrm{~W} / \mathrm{cm}^{2}$. Instantaneous etch rates in alumina/TiC ceramic of $200 \mu \mathrm{m} / \mathrm{s}$ have been observed for an incident power density of $10^{6} \mathrm{~W} / \mathrm{cm}^{2}$.

\section{Conclusion}

Experiments on laser enhanced plating and etching have demonstrated the ability to bring about plating rates as high as $10 \mu \mathrm{m} / \mathrm{s}$ which is $10^{2}$ to $10^{3}$ times as rapid as that obtainable with more conventional techniques, standard in the industry today. In certain cases, the laser enhanced technique also leads to an improvement in the quality of deposit. The pyrolitic effects caused by the laser absorption also cause localized cleaning of the substrte, thereby making it possible to obtaing on substances normally hard or impossible to plate, good adhesion of the deposit to the substrate and enhanced nucleation on the surface. The ability to confine the light to micron sized dimensions leads to maskless patterning on a micron sized scale. High speed patterning of this type is becoming increasingly interesting for circuit design, circuit repair, and localized deposits on microelectronic connector parts. Localized etching also has numerous applications in the field of microelectronics.

\section{Acknowledg ments :}

I am grateful to my colleagues with whom I have collaborated over the past several years in many of the experiments described in the text. I wish to express special gratitude to Drs. R.E. Acosta, J-Cl. Puippe, M.H. Gelchinski and L.T. Romankiw for their many contributions throughout these investigations. The invaluable assistance of D.R. Vigliotti and E.E. Tynan also are gratefully acknowleded.

\section{References :}

1) R.J. von Gutfeld, E.E. Tynan, R.L. Melcher and S.E. Blum, Appl. Phys. Lett. 35, 651 (1979).

2) R.J, von Gutfeld, E.E. Tynan and L.T. Romankiw Extended Abstract 472, p. 1185 Electrochem. Soc. Los Angeles, CA (Oct. 14-19, 1979).

3) J.Cl. Puippe, R.E. Acosta and R.J. von Gutfeld, J. Electrochem. Soc. 128, 2539 (1981).

4) R.J. von Gutfeld and J.Cl. Puippe, Oberflächel Surface 22, 294 (1981).

5) R.J. von Gutfeld, R.E. Acosta and L.T. Romankiw, IBM J. of Research and Development 26, 136 (1982).

6) R.J. von Gutfeld and L.T. Romankiw, Gold Bulletin 15, 120 (1982).

7) M.H. Gelchinski, L.T. Romankiw and R.J. von Gutfeld, Ext. Abstracts 82-2 p. 206, Electrochem. Soc., Detroit, MI (Oct. 1982).

8) R.J. von Gutfeld, M.H. Gelchinsk and L.T. Romankiw, SPIE Proc. on Conf. on Laser Processing of Semiconductor Devices 385, 118 (1983).

9) L.T. Romankiw, R.E. Acosta, M.H. Gelchinski and R.J. von Gutfeld, Proc. of Symp. on Electroplating and Waste Recycle, New Develop. and Trends, 
Cleveland, Ohio, August 30, 1982, Electrochem. Soc., Electrodeposition Div. Vol. 83-12, p. 66.

10) D.R. Turner, Thin Solid Films 95, 143 (1982).

11) H.K. Kuiken, F.E.P. Mikkers and P.E. Wierenga, J. Electrochem. Soc. 130, 554 (1983).
12) R.J. von Gutfeld, M.H. Gelchinski, L.T. Romankiw, and D.R. Vigliotti, Appl. Phys. Lett. 43, 876 (1983).

13) R.J. von Gutfeld and R.T. Hodgson. Appl. Phys. Lett. 40, 352 (1982).

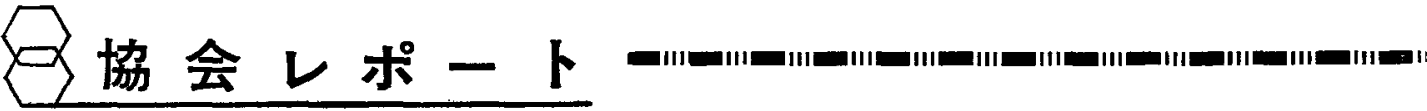

\section{第 19 回腐食・防食セミナー報告}

本委員会注昭和 28 年们岡本㓮教授を初代委員長とし て発足し，本委員会が主体となって腐食防食討論会も生 れ，腐食に括ける電気化学の重要性が徐々に認識される に至った．セミナーの No. は, 次の委員長向坊隆教授 の時（昭42）のそれが第 1 回とされ，以来向正夫教授 $\rightarrow$ 藤井晴一教授 $\rightarrow$ 田島栄教授と続き，活発なセミナーが開 かれてきた，その主なるものとしては，核生成，白金電 極, 陽極酸化皮膜, 高温酸化, 電解加工, 電池のアノー ド挙動, 化学装置と材料, インヒビター, 電気防食, 分 極測定, 腐食系における酸素の挙動, 皮膜で覆われた電 極の化学, 腐食教育, 腐食試験法の進歩, 金属の動態一 不働態を利用した電気化学的興奮模型, Al イオンの挙 動と応用等が挙げられ，きわめて有意義な講演と討議が なされてきた。

今回はその第 19 回目で,下記セミナーが行なわれた. とき 5月15日(火) $13: 00-17.00, と こ ろ$ 家の光会館 1. 溶融塩中に扝ける腐食の電気化学

溶融塭による金属の腐食を電気化学的現象として解析 し,さらに実機における電気化学的腐食モニタリング手 法についての平易な解説をする.

東京工業大学金属工学科 沼田 博雄

\section{2. 金属の不働態皮膜について}

皮膜破壞現象とその理論, 特に破壊に及ぼす電歪の影 響, 皮膜自体の耐食性, 皮膜の半導体的特性と腐食との 関連性等について解説する.

\section{北海道大学工学部 佐藤 教男}

3. パネルディスカッション

パネラー 高橋正雄, 石川達雄, 杉本克久, 加藤正義 講演 1 の沼田氏は最近Texas A and M Univ. の Prof. Bockris の下で 2 年間溶融塩腐食の研究をしてこられた 新進の化学者である. 本講演では溶融塩中におう打金属 の腐食研究が，新エネルギー源の開発汇関連して最近特 に重要視されてきたことが強調された。そしてこの腐食 系でも水溶液中に扔けると同様に, 混成電位説に従らこ とが示され，また熱力学的データーからいろいろな系で
の電位- $\mathrm{pO}^{2-}$ 線図が紹介され，その有用性が指摘され た.また各種プラントや原子炬における腐食速度のモ二 タリングの重要性が述べられ，アノード分極特性, 分極 抵抗および交流式腐食モニター法の溶融塩系一の適用例 が数多く紹介された。これに対する討議として石川教授 より「分極時の電流は溶融塩の酸化, 還元電流なのか, 金属の溶解, 析出電流なのか, その中味を知る必要があ る」といらコメントが出された，高橋教授は, 溶融塩の 塩基度と酸素／超酸化物イオン／過酸化物イオン／酸化 物イオン間の平衡図について説明されこの平衡が第二 世代然料電池の酸素極の反応機構上関連して重要である ことを指摘された。杉本教授注合金系の表面皮膜は深さ 方向に不均一で多層構造となり, 組成, 結晶構造によっ て厚さが異なることを電顕写真によって示された。

講演 2 の任藤教授仕昨年米国電気化学会上り, Outstanding Achievement Award of the Corrosion Division を受賞されたので，今回はその内容の一部を紹介して頂 いた，その内容は，1．金属表面不働態皮膜，2，表面電 気二重層，3．皮膜の溶解，4. 皮膜の破填上り成り，各 項目について演者の永年にわたる研究成果が平易に解説 された。1で注皮膜は厚さ $0.5 \sim 5 \mathrm{~nm}$ 程度の非晶質あ るいはガラス状の酸化物および含水酸化物で, 高密度な 構造欠宿を含さ半導体あるいは絶縁体とみられること， 2 で法電気二重層の電位差が液の $\mathrm{pH}$ 亿依存する一定值 をとるが，その電位分布はまだ明確ではない等の説明が あった３では酸化物の自然溶解はへルムホルッ層の電 位美に支配されることや酸化物皮膜の電気化学的分解の 機構が述べられ，4 では全面破壊と局部破壊の機構の説 明があり，特に電歪応力に上る絶縁破壊現象の説明は興 味深かった。

最後に岡本教授が不働態研究に対するコメントを出さ れ「この研究は皮膜の Surface Characterization だけで は不十分であり，もっと溶液中の on site での動的挙動, 特に皮膜の self repairing に注目する必要がある」こ とを強調された。

（本会腐食専門委員会委員長 加藤正義） 